\title{
CASE STUDY OF SELECTED NATURE SWIMMING POOLS IN THE SOUTH MORAVIAN REGION
}

\author{
TEREZA POLOPRUTSKÁ ${ }^{1}$, MICHAL NOVÁČEK $\mathbb{\triangle}^{2}$, PETRA OPPELTOVÁ ${ }^{1}$ \\ ${ }^{1}$ Department of Applied and Landscape Ecology, Faculty of Agronomy, Mendel University in Brno, Zemědělská 1, 61300 Brno, The Czech Republic \\ ${ }^{2}$ Institute of Computer Aided Engineering and Computer Science, Faculty of Civil Engineering, Brno University of Technology, Veveří 95, 602 00 Brno, The \\ Czech Republic; e-mail: michal.novacek93@seznam.cz
}

$\bowtie$ Corresponding author

Received: 18 May 2021 / Accepted: 14 September 2021

Abstract

Poloprutská T., Nováček M., Oppeltová P.: Case study of selected nature swimming pools in the South Moravian Region. Ekológia (Bratislava), Vol. 40, No. 4, p. 312-324, 2021.

\begin{abstract}
Nature swimming pools are a sought-after alternative to conventional swimming pools. Their natural water purification system, without the need for chemicals, is beneficial to health and environmentally friendly. Designing such a nature swimming pool is a complex matter because it requires coordination of a number of effects, which can easily cause an imbalance in the entire system. This work uses the case study method to analyse the overall condition of three nature swimming pools in the South Moravian Region during the second half of the swimming pool operation season.
\end{abstract}

Key words: water, swimming area, regeneration area, nutrients, water trophy.

\section{Introduction}

Nature swimming pools are an alternative to conventional swimming pools which utilise chemical water treatment methods. The water in nature swimming pools is not cleaned chemically, but biologically and mechanically (Littlewood, 2005). This difference has benefits in the form of a healthy bathing environment, which does not have any negative impact on human health because no chlorine is used (Bernard et al., 2009). However, it also has specific limitations, which include a limited number of bathers and stricter requirements for the correct design of the swimming pool in order to achieve a balanced ecosystem (Pavlis, 2017).

Design of a nature swimming pool and its maintenance are problematic because efforts need to be made to keep the amount of nutrients in this system as low as possible (Association of nature swimming pools and ponds, 2014). It is difficult to rectify the amount of nutrients in such a complex nature system. Extensive technologies and chemical additives are used to treat water by conventional water management methods (Bratby, 2016). We essentially wish to avoid use of these technologies in nature swimming pools. This is why, the design is based on natural water treatment methods (Sperling, 2007), which we apply on various scales using with the least possible technology. The main natural processes utilised in nature swimming pools are filtration, which can remove substances depending on the filtration material used (Karczmarczyk et al., 2019), removal of substances utilising vegetation (Guardia-Puebla et al., 2019) and potentially sedimentation in swimming pools without water circulation systems. There are a number of factors influencing these natural processes, and it is, therefore, very difficult to design a water ecosystem such that it remains balanced and meets our requirements (Pavlis, 2017). In contrast to the conventional chemical method of water purification, all changes using the natural purification method take place much more slowly and after a specific interval, which is why the stability of the ecosystem is so important.

This paper contains an analysis of the condition of three selected nature swimming pools in the South Moravian Region. These are locations in the municipalities of Oslavany, Kovalovice and Bohuslavice u Kyjova.

The general design of nature swimming pools and swimming ponds includes a main swimming area for users and a regeneration area, which is intended for removing contaminants (nutrients) from the swimming area (Von Berger, 2010).

Depending on the type, artificial swimming pools can be divided into nature swimming pools and swimming ponds (Association of nature swimming pools and ponds, 2014). Nature swimming pools are a closed system with an assured water circulation system. Swimming ponds do not have a circulation system and contain standing water (Association of nature swimming pools and ponds, 2014). On the basis of this definition, all the analysed artificial natural pools are nature swimming pools.

Due to their nature, nature swimming pools contain oligotrophic water (Association of nature swimming pools and ponds, 2014), which is water with a low nutrient content (Pitter, 2015). The overall nature swimming pool system consists of a closed water circulation system, when water from the swimming

(C) The Author(s) 2021. This is an open access article distributed under the terms of the CC BY-NC-ND license.

https://content.sciendo.com/view/journals/eko/eko-overview.xml 


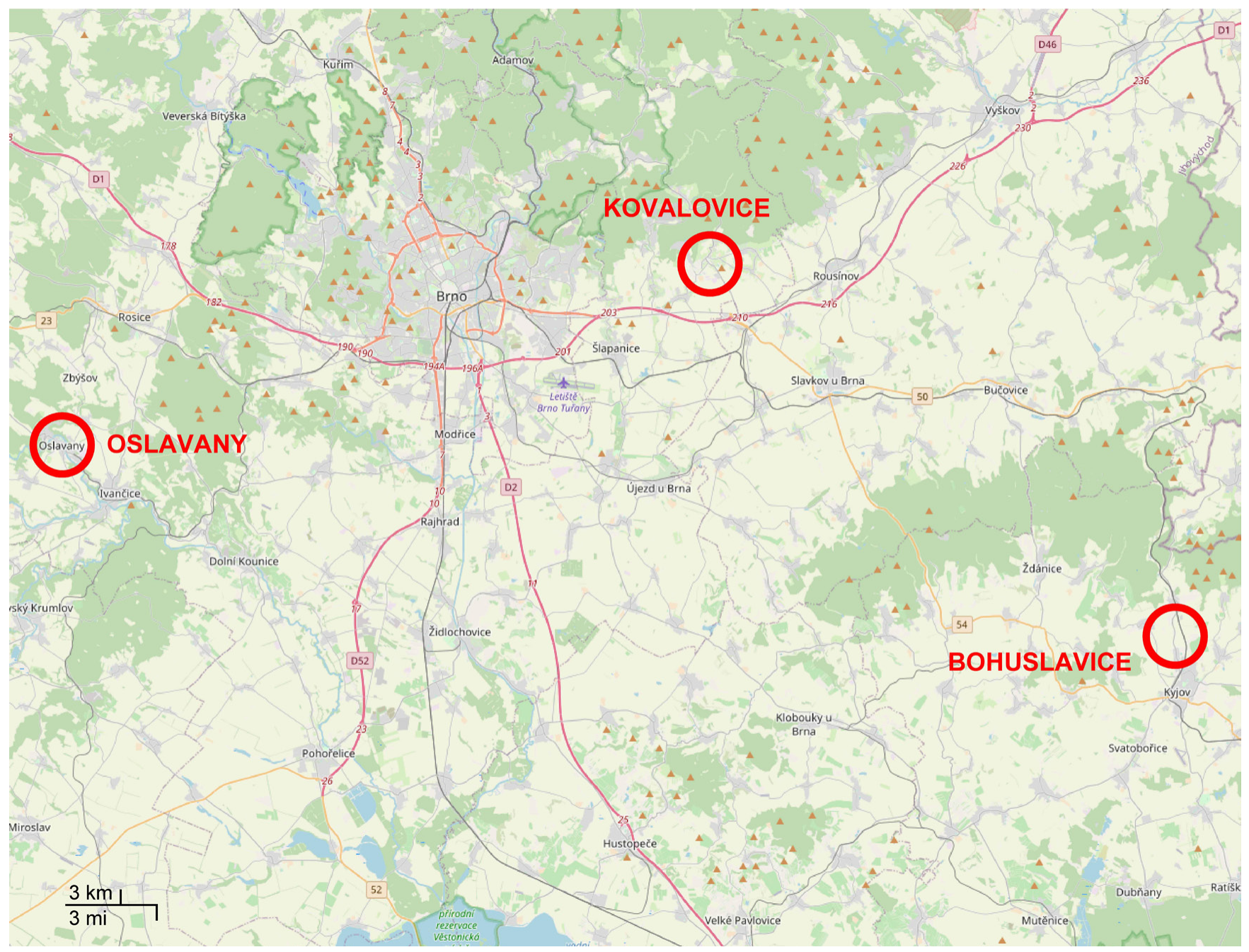

Fig. 1. Locations of the examined nature swimming pools. Source: Open Street Map.

Table 1. Chemical composition and geometric parameter values of a swimming pool recommended by the standards (Association of nature swimming pools and ponds, 2014).

\begin{tabular}{|l|c|c|c|c|}
\hline & Type of swimming pool & P-total (mg/l) & $\mathbf{p H}(-)$ & $\begin{array}{c}\text { Ratio of regeneration area } \\
\text { to swimming area (\%) }\end{array}$ \\
\hline \multirow{3}{*}{ Standing water } & & & & $40: 60$ \\
\cline { 2 - 5 } & 1 & $<0.035$ & $8.0-8.5$ & $50: 50$ \\
\hline \multirow{2}{*}{ Circulating water } & 2 & $<0.035$ & $8.0-8.5$ & $50-60: 50-40$ \\
\cline { 2 - 5 } & 3 & $<0.035$ & $8.0-8.5$ & $70: 30$ \\
\hline
\end{tabular}

Note: an swimming pool type 3, the circulation system is used for a maximum of 2 hours a day.

area is continuously pumped into the regeneration area, where the nutrients it contains are removed utilising a filtration and biological treatment system (utilising phytoplankton, zooplankton and macrophytes) (Baumhauer, Schmidt, 2008). This system has no outflow and water can only be added to the pool when it evaporates. The water added to the pool should contain as few nutrients as possible to maintain its oligotrophic nature (Pavlis, 2017).
In the public nature swimming pools of the Czech Republic, the water samples have to be collected and analysed on a monthly basis as per the requirements of the relevant Regional Hygiene Station (Decree No. 238/2011 Coll., 2011). In this case, key indicators are the amount of Escherichia coli, water transparency and the amount of Enterococcus. These parameters are crucial for the health of bathers (Giampaoli et al., 2014). However, they may not serve as evidence of the complex condition of the nature swimming pool. 


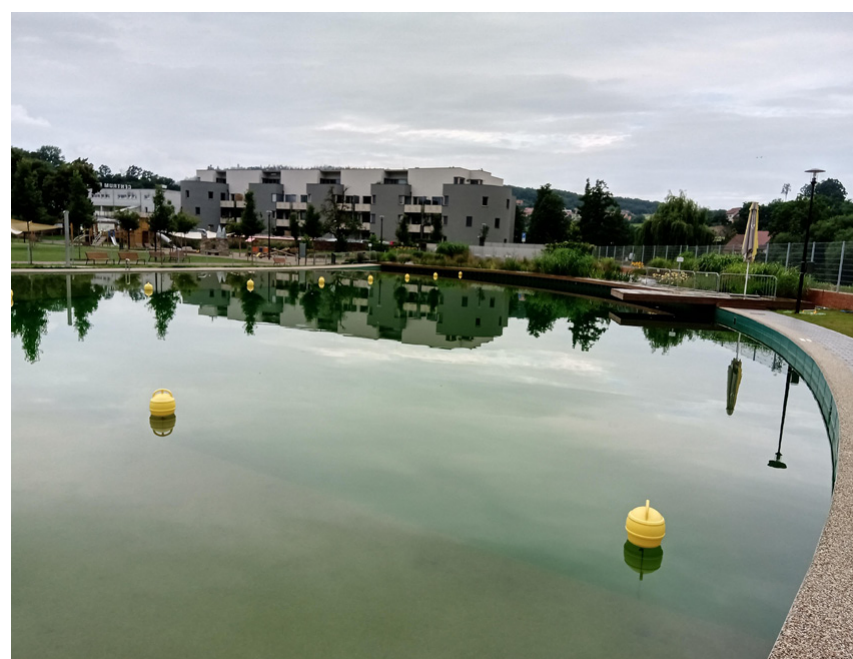

Fig. 2. Swimming section of the nature swimming pool in Oslavany. Source: author's archive.

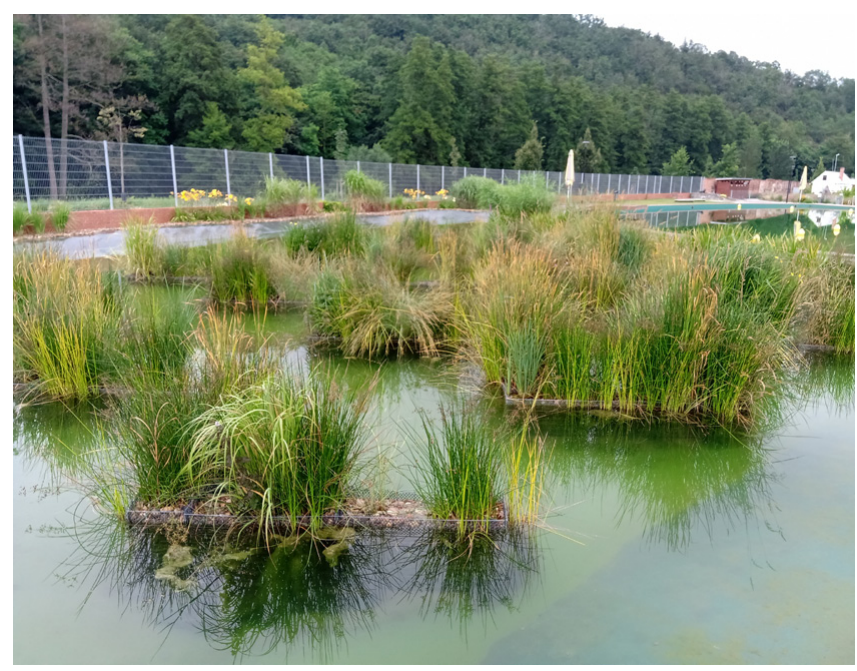

Fig. 3. Filtration walls with vegetation in the regeneration section in Oslavany. Source: author's archive.

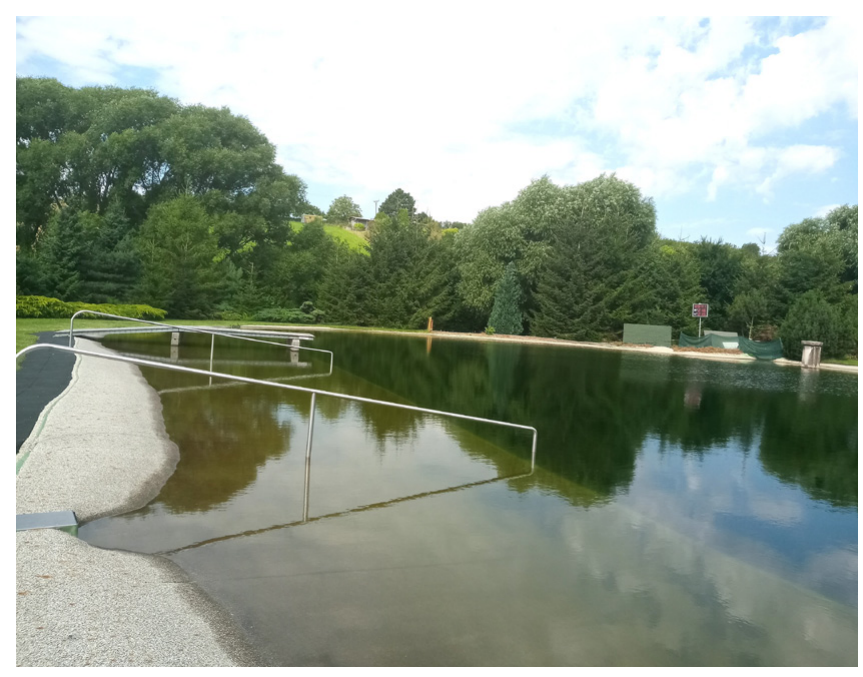

Fig. 4. Swimming section of the nature swimming pool in Kovalovice. Source: author's archive.

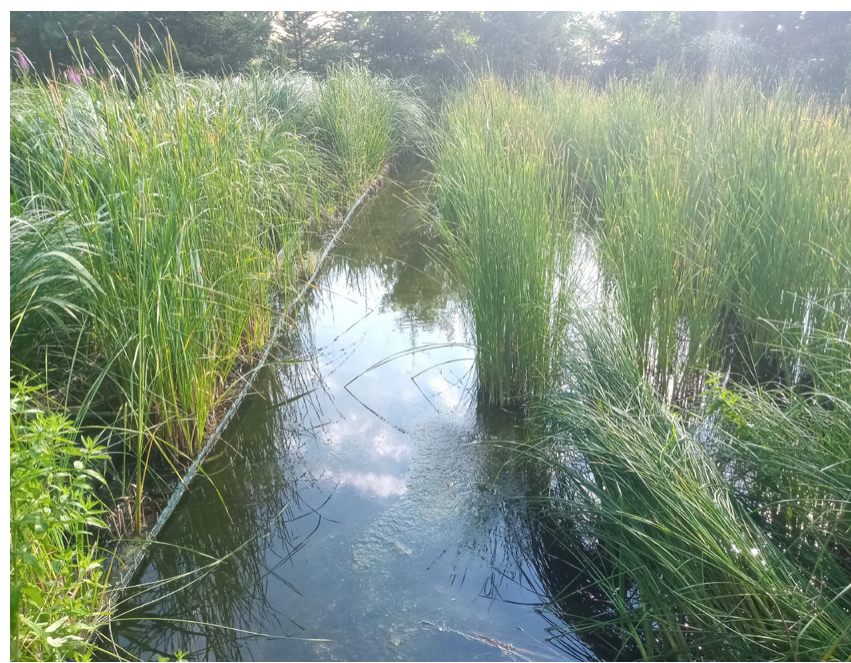

Fig. 5. System of dams in the regeneration section in Kovalovice. Source: author's archive.

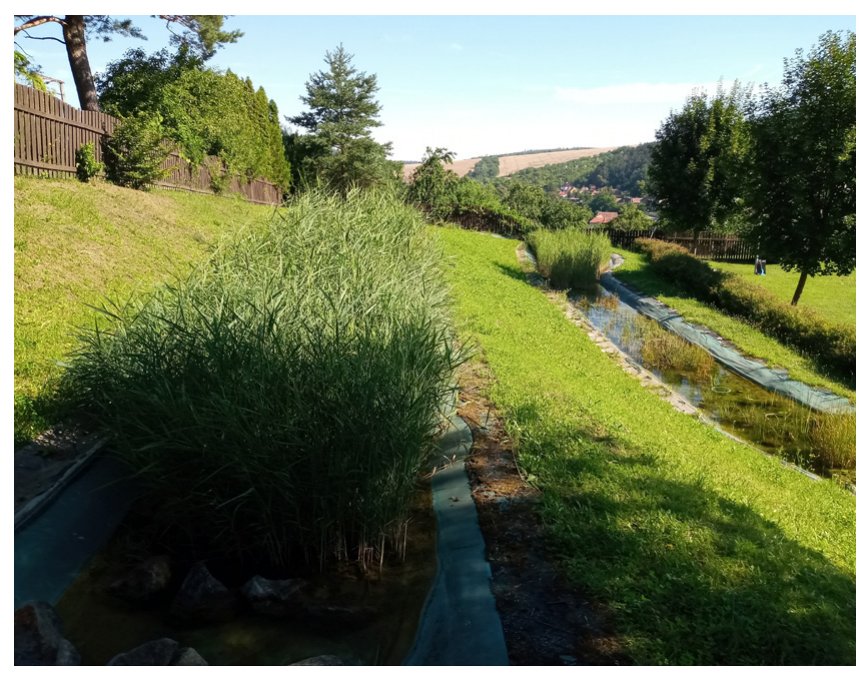

Fig. 6. Linear-shaped regeneration section in Bohuslavice u Kyjova. Source: author's archive.

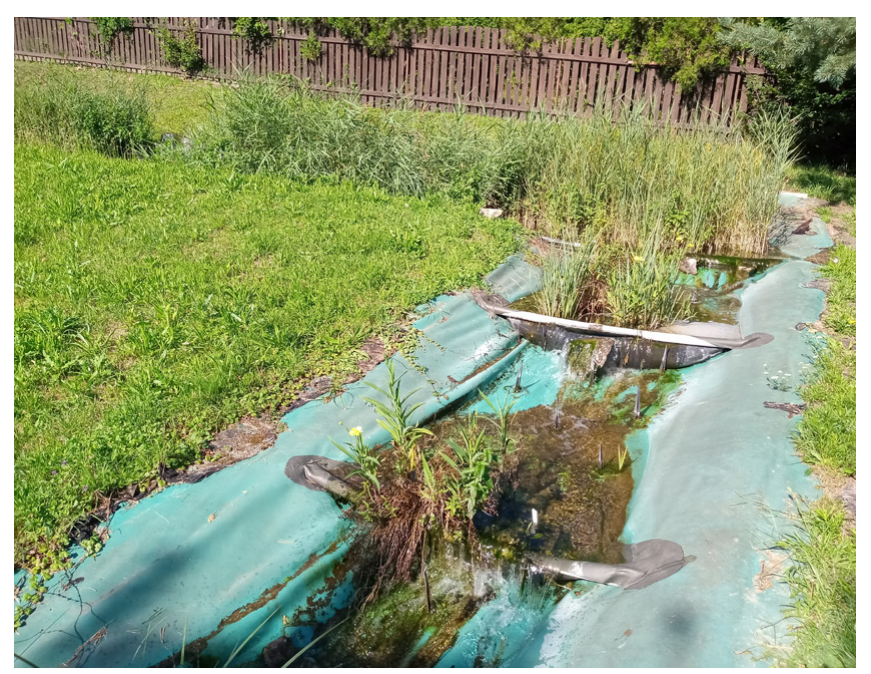

Fig. 7. Cascade in the regeneration section in Bohuslavice u Kyjova. Source: author's archive. 
Table 2. Geometric parameters of the examined nature swimming pools.

\begin{tabular}{|l|c|c|c|c|c|c|c|}
\hline & \multicolumn{3}{|c|}{ Regeneration section } & \multicolumn{3}{c|}{ Swimming section } & Regeneration and swimming area ratio \\
\hline & Vol. $\left(\mathbf{m}^{3}\right)$ & Area $\left(\mathbf{m}^{\mathbf{2}}\right)$ & Depth $(\mathbf{m})$ & Vol. $\left(\mathbf{m}^{\mathbf{3}}\right)$ & Area $\left(\mathbf{m}^{\mathbf{2}}\right)$ & Max. depth $(\mathbf{m})$ & Regeneration area:swimming area \\
\hline Oslavany & 375 & 515 & 0.7 & 1450 & 1200 & 2.5 & $30.0: 70.0$ \\
\hline Kovalovice & 250 & 500 & 0.5 & 3700 & 1000 & 4.2 & $33.3: 66.7$ \\
\hline Bohuslavice & 50 & 175 & 0.3 & 780 & 574 & 2.85 & $23.4: 76.6$ \\
\hline
\end{tabular}

Table 3. Presence of facilities for visitors and the method of treating water in the examined complexes.

\begin{tabular}{|l|c|c|c|c|}
\hline & Shower & Aeration & Long-term records of the number of visitors & Water filtration through screen \\
\hline Oslavany & Yes & Yes & No & Yes \\
\hline Kovalovice & Yes & No & Yes & Yes \\
\hline Bohuslavice & Yes & No & Yes & No \\
\hline
\end{tabular}

The main indicator of water pollution from the water management aspect is the presence of nutrients (Håkanson, Bryhn, 2008). In the presence of high concentrations of key nutrients, which are especially nitrogen and phosphorus compounds, algae and cyanobacteria reproduce excessively in the water, thereby causing the water quality to decline (McGriff, McKinney, 1972). The result of this abundant reproduction is mainly a decline in water transparency, which results in unsatisfactory hygienic conditions for operation of the facility. This poor condition may be caused by an increased presence of nutrients, whereas the decline in degree of water transparency is a consequence of this poor condition (Håkanson, Bryhn, 2008).

There are some recommended standards for designing swimming ponds and nature swimming pools in the Czech Republic. These standards give the geometric parameters and the chemical and physical indicators recommended for construction (Association of nature swimming pools and ponds, 2014). The values of these indicators are given in Table 1 . However, there are no general methods that can be used to create a nature swimming pool design and guarantee a specific water quality. This is particularly because of the complexity of the entire issue as there are a number of issues that affect water quality in a nature swimming pool.

\section{Material and methods}

The nature swimming pools were chosen with regard to the distances between them. They are all located in the South Moravian Region. This means that relatively similar climatic conditions can be assumed. They are also located at similar altitudes. Access to each complex was arranged in advance with the operator. Access was always assured before opening. This eliminated the direct impact of bathers on the results of research. The locations of the analysed nature swimming pools are clearly given in Fig. 1.

\section{Oslavany}

The nature swimming pool in Oslavany is located in the complex of the local château at an above-sea-level of approximately 220 m.a.s.l. This is the newest nature swimming pool in the investigated sample (constructed in 2019). This is also the nature swimming pool with the largest swimming and regeneration area. The complex also contains sanitary facilities and a shower with cold water from the water mains next to the nature swimming pool. A bored well provides additional water.

The swimming area (Fig. 2) is divided into a deep swimming section with an area of approximately $600 \mathrm{~m}^{2}$ and a depth of $2.5 \mathrm{~m}$ and a shallow section with a depth of up to $1.4 \mathrm{~m}$ and an area of approximately $600 \mathrm{~m}^{2}$. The total volume of the swimming section is approximately $1.450 \mathrm{~m}^{3}$. The pool is lined with exterior swimming pool sheeting and embedded into a concrete shell, with vertical walls on one side and a gradual entrance inclined into the water on the other side.

Water is removed from the surface of the swimming section using skimmers and pumped into the pre-treatment zone. This nature swimming pool is the only one of the examined group with a pre-treatment system before the regeneration zone, which filters the water through fabric and subsequently aerates it using compressors. The pre-treated water is then pumped into the regeneration zone (Fig. 3).

The regeneration section, with an area of approximately $515 \mathrm{~m}^{2}$ and a volume of $375 \mathrm{~m}^{3}$, contains a layer of gravel on the bottom and also a number of thin, separate, vertical walls made from filtration material with a cover of vegetation, which is visible in Fig. 3. These walls are located in the direction of the natural water flow and prolong the time the water stays in this section.

The maximum number of visitors to the swimming pool at one time is limited. The management of the complex does not keep long-term records of the number of visitors.

\section{Kovalovice}

The nature swimming pool in Kovalovice is located on the bank of Kovalovice stream, at an above-sea-level of approximately 270 m.a.s.l. This nature swimming pool was the first nature swimming pool to be established in the Czech Republic in 2007. This is the second biggest (by area) swimming pool in the examined sample. The complex also contains sanitary facilities, including cold water showers. A bored well supplies additional water.

The swimming area (Fig. 4) consists of a small paddling pool and a large swimming pool. The paddling pool is separated from the main pool and was not the subject of this research. The main swimming pool, with an area of approximately $1000 \mathrm{~m}^{2}$ and a vol- 


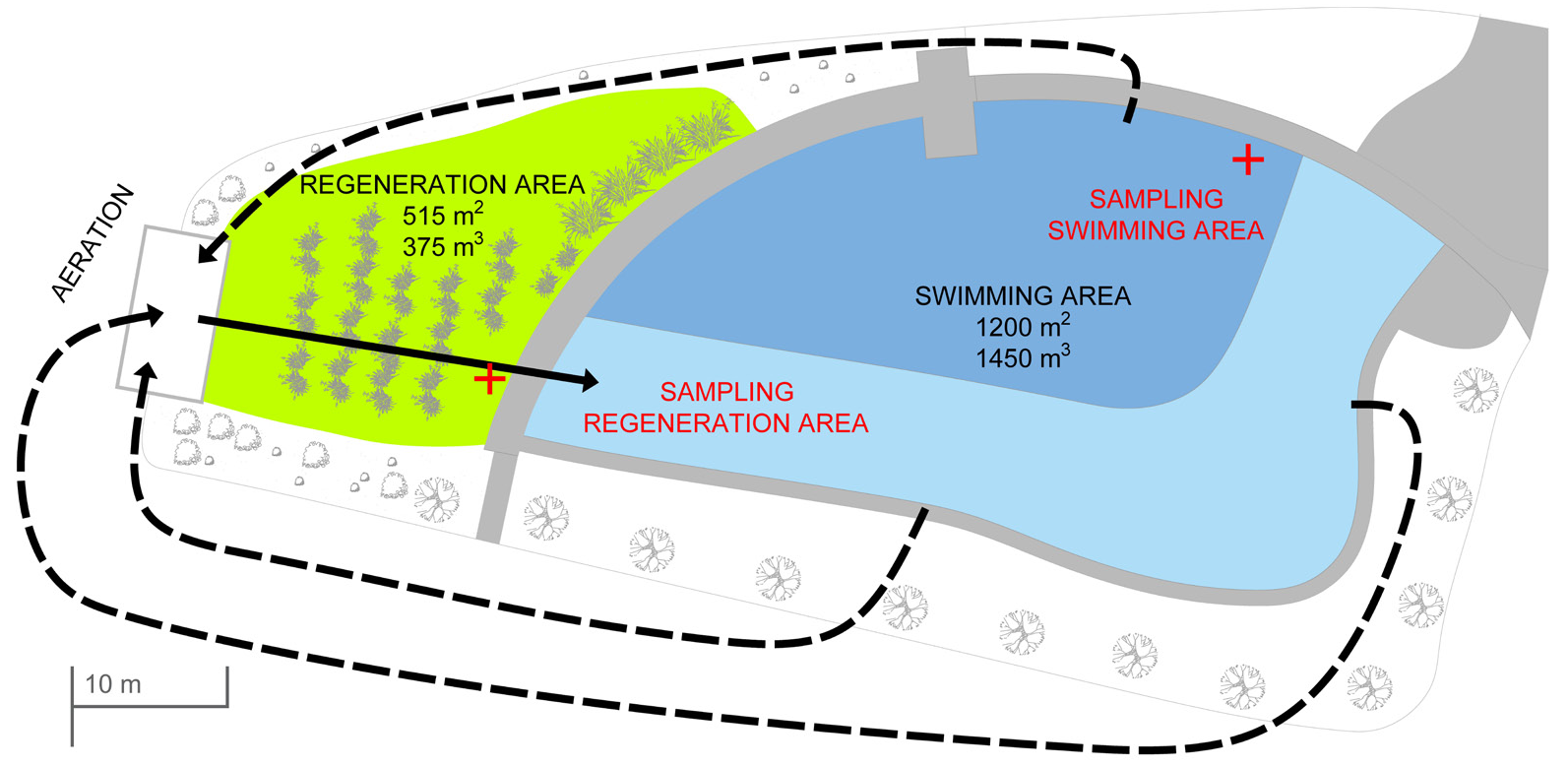

Fig. 8. Collection sites and depiction of functionality in a diagram of the nature swimming pool in Oslavany. The deep part of the swimming section is coloured dark blue and the shallow part is coloured light blue. Source: author's archive.

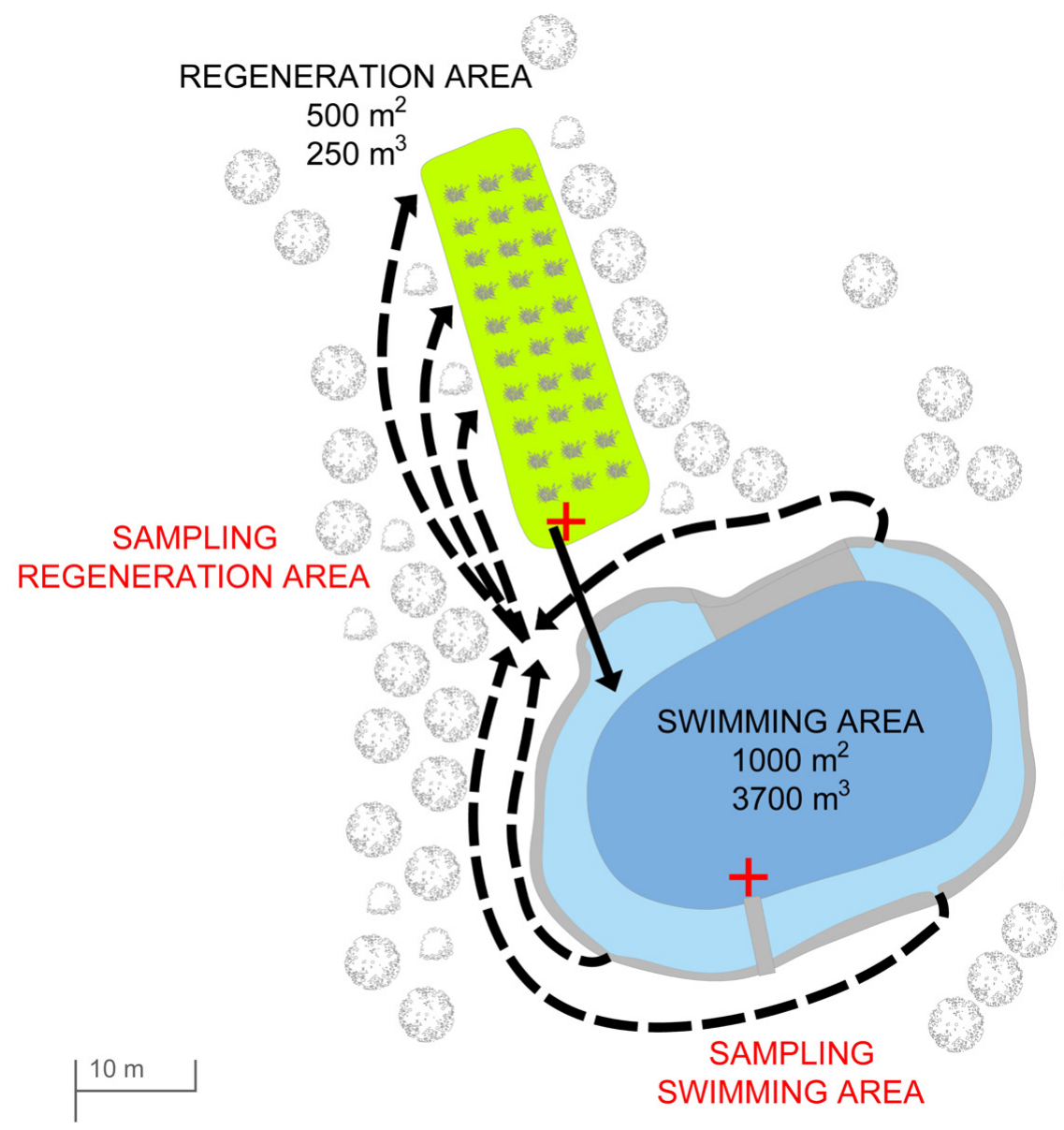

Fig. 9. Collection sites and depiction of functionality in a diagram of the nature swimming pool in Kovalovice. The deep part of the swimming section is coloured dark blue and the shallow part is coloured light blue. Source: author's archive. 


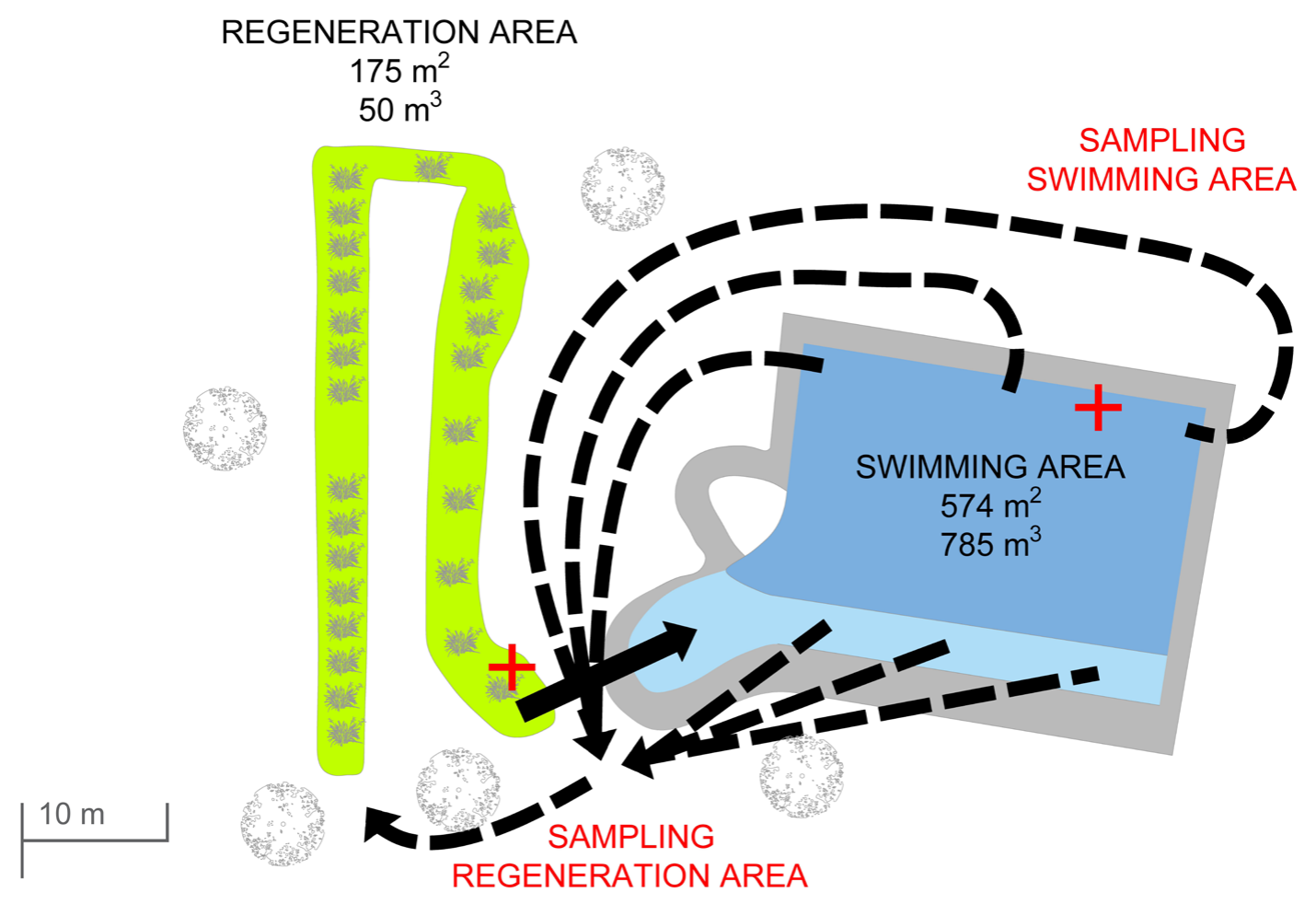

Fig. 10. Collection sites and depiction of functionality in a diagram of the nature swimming pool in Bohuslavice u Kyjova. The deep part of the swimming section is coloured dark blue and the shallow part is coloured light blue. Source: author's archive.

ume of $3700 \mathrm{~m}^{3}$, has an elliptical shape with a gradual incline into the water up to a depth of $1.0 \mathrm{~m}$. The entrance incline crosses into a deep pool with vertical walls, which reaches a depth of $4.2 \mathrm{~m}$. This is, therefore, the deepest of the examined nature swimming pools, with the greatest volume. The surface of the pool consists of a pebble in cement screed on the shallow, inclined banks and concrete blocks lining the deep section, without a finishing layer.

The water is removed from the surface of the swimming section through three skimmers into the regeneration zone, where it is filtered at the inlet through a very rough screen, without fabric. The water can also be pumped from around the perimeter of the deep swimming section (at approximately the middle of the depth) and also by a pipe from the bottom of the pool. There are three pumps installed in the complex for moving the water.

The regeneration zone is of rectangular shape, with an area of approximately $500 \mathrm{~m}^{2}$ and a volume of $250 \mathrm{~m}^{3}$ (the volume is determined on the basis of the depth of the mud bottom of the regeneration section). The entire area is dammed by a transverse system of dams (Fig. 5), which are planted extensively with vegetation. This nature swimming pool has the greatest proportion of vegetation per area of regeneration section. The density of the vegetation within the area of the regeneration section also assures significant slowing of the water flow. The water is filtered through a fine fabric at the outlet from the regeneration section.

The management of the complex determines the maximum number of visitors and keeps long-term records of the number of visitors.

\section{Bohuslavice u Kyjova}

The nature swimming pool in Bohuslavice u Kyjova is located on the steep, north-facing slope of a mountain, at an above-sealevel of approximately 230 m.a.s.l. It originated by conversion of a former conventional swimming pool into a nature swimming pool. The conversion was executed in 2013. This is the smallest (by area and volume) swimming pool of the sample of examined swimming pools. There are sufficient sanitary facilities and also a cold water shower in the complex due to the previous function of the area.

The swimming section originated on the site of the pool at the previous conventions facility. This pool, of a rectangular shape, was retained, but one side was modified and a gradual incline into the water was created. There is a filtration bed built into the site of the incline, which no longer fulfils its role, however. The pool has an area of $574 \mathrm{~m}^{2}$ and a volume of $780 \mathrm{~m}^{3}$. The maximum depth at the transition site of the pool is $1.2 \mathrm{~m}$. The depth of the main swimming pool is $2.85 \mathrm{~m}$. The entire bottom of the pool is covered in swimming pool sheeting.

The water is removed from the surface into the regeneration section using three skimmers and a pump, possibly from the filtration bed using a pump.

The regeneration section is usually in the form of a linear element (trough), which overcomes a height difference of over $2 \mathrm{~m}$, over a length of approximately $80 \mathrm{~m}$, which is visible in Fig. 6. This height difference is overcome using a system of small dams (see Fig. 7) over which the water overflows. This is a so- 
Table 4. Results obtained from analysis of samples.

\begin{tabular}{|c|c|c|c|c|c|c|c|}
\hline Pool & Zone & $\mathrm{N}-\mathrm{NO}_{3}(\mathrm{mg} / \mathrm{l})$ & $\mathrm{P}_{-} \mathrm{PO}_{4}(\mathrm{mg} / \mathrm{l})$ & P-total (mg/l) & Chlorophyll-a $(\mu \mathrm{g} / \mathrm{l})$ & $\mathrm{O}_{2}(\mathrm{mg} / \mathrm{l})$ & pH (-) \\
\hline \multirow{8}{*}{ 预 } & \multirow{4}{*}{$\begin{array}{l}\text { Regeneration } \\
\text { section }\end{array}$} & 13.0 & $<0.010$ & 0.011 & 7.1 & 8.41 & 6.51 \\
\hline & & 18.0 & $<0.010$ & 0.013 & 24.0 & 7.29 & 6.33 \\
\hline & & 14.0 & $<0.010$ & 0.017 & 4.8 & 6.65 & 6.95 \\
\hline & & 14.0 & $<0.010$ & 0.013 & 25.0 & 9.70 & 7.60 \\
\hline & \multirow{4}{*}{$\begin{array}{l}\text { Swimming } \\
\text { section }\end{array}$} & 17.0 & 0.55 & 0.012 & 8.1 & 10.06 & 7.40 \\
\hline & & 18.0 & $<0.010$ & 0.019 & 41.0 & 11.98 & 8.16 \\
\hline & & 14.0 & $<0.010$ & 0.013 & 17.0 & 9.19 & 7.40 \\
\hline & & 5.0 & $<0.010$ & 0.015 & 28.0 & 11.21 & 8.41 \\
\hline \multirow{8}{*}{ 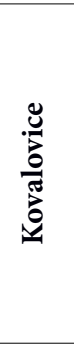 } & \multirow{4}{*}{$\begin{array}{l}\text { Regeneration } \\
\text { section }\end{array}$} & $<0.1$ & $<0.010$ & 0.014 & 17.0 & 8.85 & 6.55 \\
\hline & & 0.2 & $<0.010$ & 0.021 & 10.0 & 2.63 & 6.48 \\
\hline & & 0.6 & $<0.010$ & 0.014 & 7.3 & 2.84 & 6.81 \\
\hline & & 0.7 & $<0.010$ & 0.012 & 4.4 & 8.73 & 6.66 \\
\hline & \multirow{4}{*}{$\begin{array}{l}\text { Swimming } \\
\text { section }\end{array}$} & $<0.1$ & $<0.010$ & 0.014 & 22.0 & 12.34 & 6.65 \\
\hline & & 0.1 & $<0.010$ & 0.023 & 17.0 & 8.19 & 7.13 \\
\hline & & 0.4 & $<0.010$ & 0.014 & 8.2 & 7.63 & 7.09 \\
\hline & & 0.6 & $<0.010$ & 0.012 & 4.4 & 10.19 & 6.81 \\
\hline \multirow{6}{*}{ 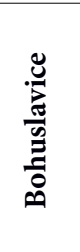 } & \multirow{3}{*}{$\begin{array}{l}\text { Regeneration } \\
\text { section }\end{array}$} & 1.5 & $<0.010$ & 0.007 & 1.9 & 8.59 & 7.58 \\
\hline & & 2.9 & $<0.010$ & 0.009 & 6.0 & 9.17 & 7.26 \\
\hline & & 2.5 & $<0.010$ & 0.011 & 4.6 & 10.00 & 7.29 \\
\hline & \multirow{3}{*}{$\begin{array}{l}\text { Swimming } \\
\text { section }\end{array}$} & 1.4 & $<0.010$ & 0.013 & 4.7 & 8.05 & 7.04 \\
\hline & & 2.1 & $<0.010$ & 0.019 & 21.0 & 10.03 & 7.25 \\
\hline & & 1.6 & $<0.010$ & 0.009 & 16.0 & 11.51 & 6.95 \\
\hline
\end{tabular}

lution created tailored for the sloping terrain. The total area of the regeneration section is approximately $175 \mathrm{~m}^{2}$, with a volume of approximately $50 \mathrm{~m}^{3}$. The bottom of the trough of the regeneration section is partially filled with substrate and planted with abundant vegetation. However, the height of the substrate and the depth of the water are very small and the water only remains in the regeneration zone for a short period.

The management of the complex in Bohuslavice $u$ Kyjova keeps a long-term record of the number of visitors. The nature swimming pool is supplied with water from the local water mains.A clear definition of the geometric parameters of the individual analysed nature swimming pools is given in Table 2. Along with the geometric parameters, additional information was also obtained concerning the equipment and functioning of the nature swimming pools, which could affect the quality of the water. This information given in Table 3.

Samples were taken four times from two nature swimming pools and three times from one swimming pool, at intervals of approximately 2 weeks between the collection of samples.

Samples of water were taken from the regeneration section and from the swimming section of each nature swimming pool. Samples from the regeneration section were collected right in front of the inlet into the swimming section. Samples from the swimming section were always collected from the opposite end to the inlet and also outside the reach of the skimmers. The collection sites are presented in Figs 8-10.

During collection at the specific site, the quality of the water was analysed using a Hach multimeter, which was used to establish the values of the amount of dissolved oxygen in water, the $\mathrm{pH}$ value and temperature.
This was followed by actual collection of samples for analysis of $\mathrm{N}-\mathrm{NO}_{3}, \mathrm{P}_{-} \mathrm{PO}_{4}$, total phosphorus and chlorophyll-a.

All probes and containers that came into contact with the collected water were always carefully rinsed with distilled water.

The collection sites, including the schematic diagram of the functionality of the nature swimming pools, are depicted in Figs 8-10.All the samples were subjected to a laboratory analysis arranged by Povodí Vltavy. The accredited laboratory of the Povodí Vltavy, State Enterprise, carried out the laboratory analysis.

The obtained values of the chemical indicators were processed into tables, for which the median value and standard deviation were calculated. The median values of the chemical indicators, with designation of 25 and $75 \%$ quantile, for the regeneration and swimming sections of each of the examined swimming pools are expressed graphically. The median of the values obtained is marked in red, the $25 \%$ quartile defined by the bottom boundary of the blue rectangle and the $75 \%$ quartile is designated by the upper boundary of the rectangle of the box graph. The minimum and maximum measured values are also entered into the graph.

\section{Results and discussion}

The results of laboratory analysis are presented in Table 4 . A total of four samples were collected for the nature swimming pools in Oslavany and Kovalovice. Only three samples were collected for the nature swimming pool in Bohuslavice.

Comparison of the median individual chemical indicators in the examined nature swimming pools is depicted in the following figures: total phosphorous in Fig. 11, $\mathrm{N}-\mathrm{NO}_{3}$ values in 


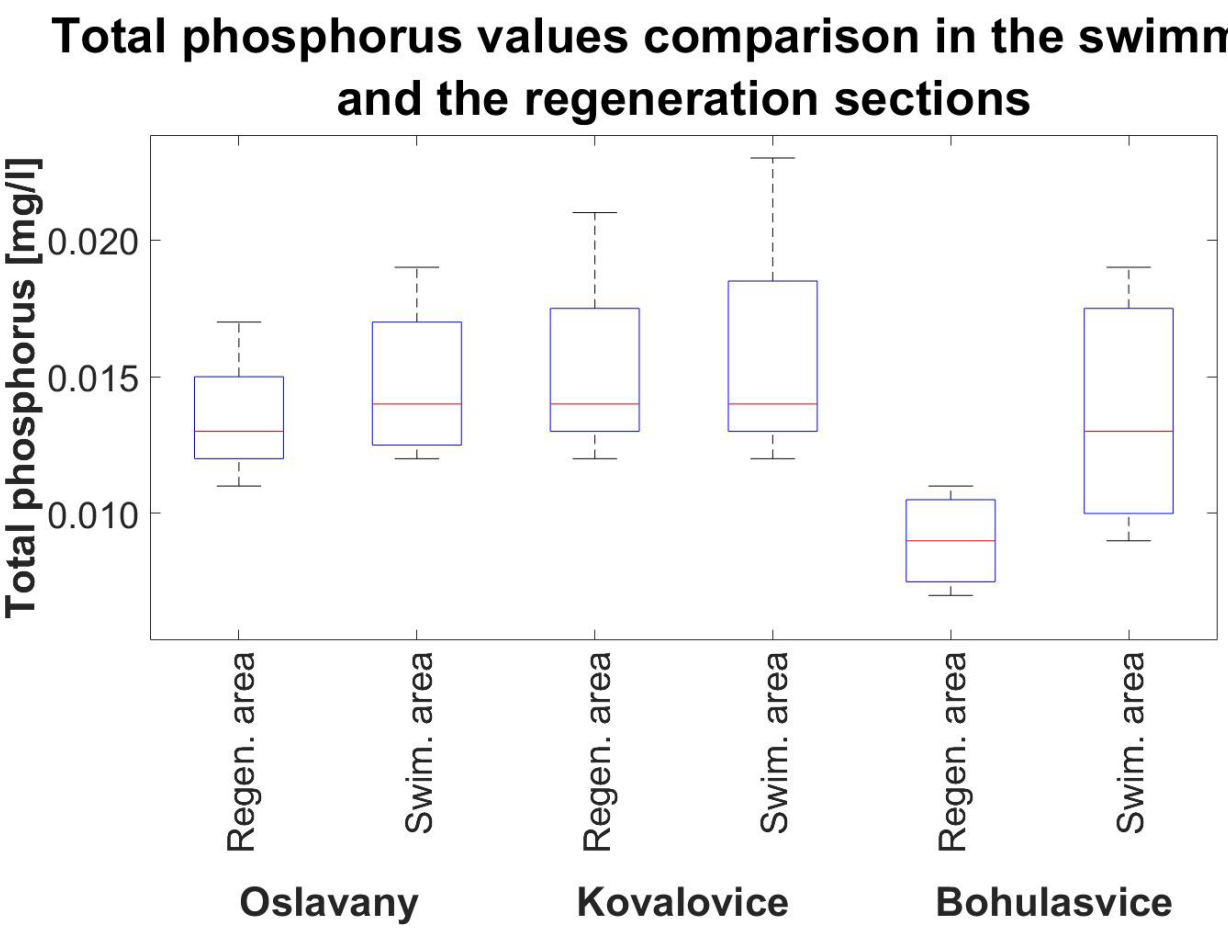

Fig. 11. Comparison of total phosphorus values in the regeneration and swimming sections. Source: author's archive.

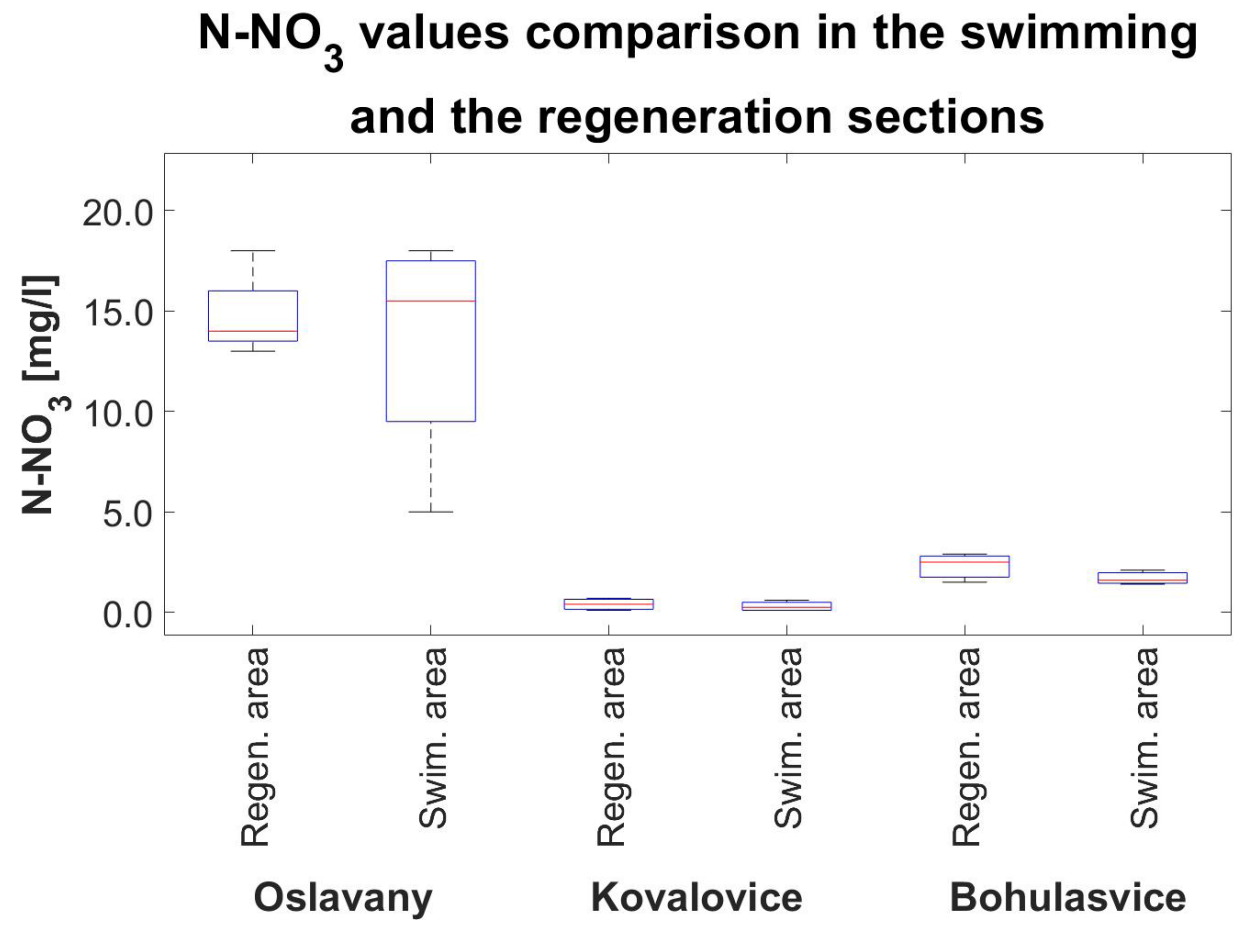

Fig. 12. Comparison of $\mathrm{N}^{-N_{3}}$ values in the regeneration and swimming sections. Source: author's archive. 


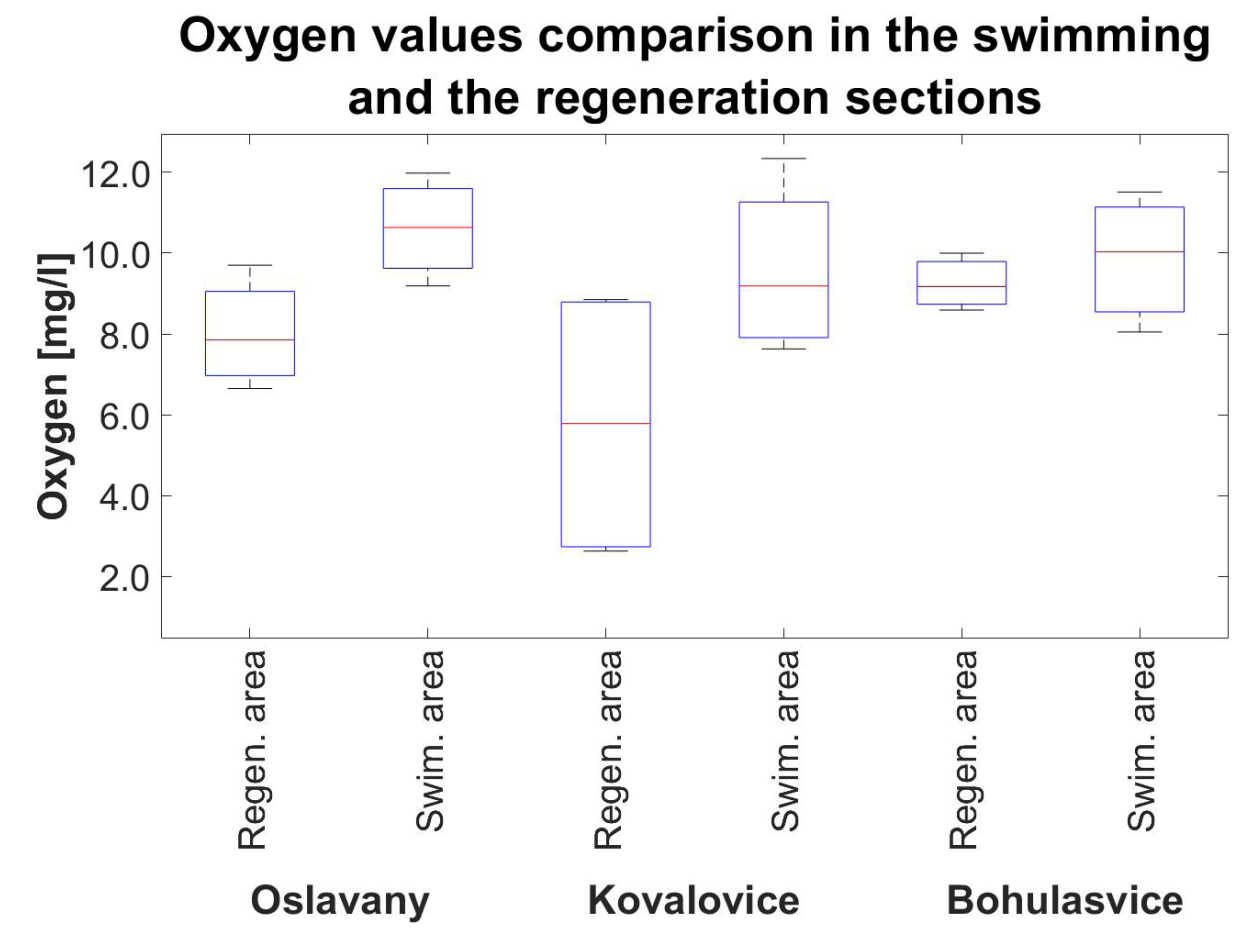

Fig. 13. Comparison of dissolved oxygen values in the regeneration and swimming sections. Source: author's archive.

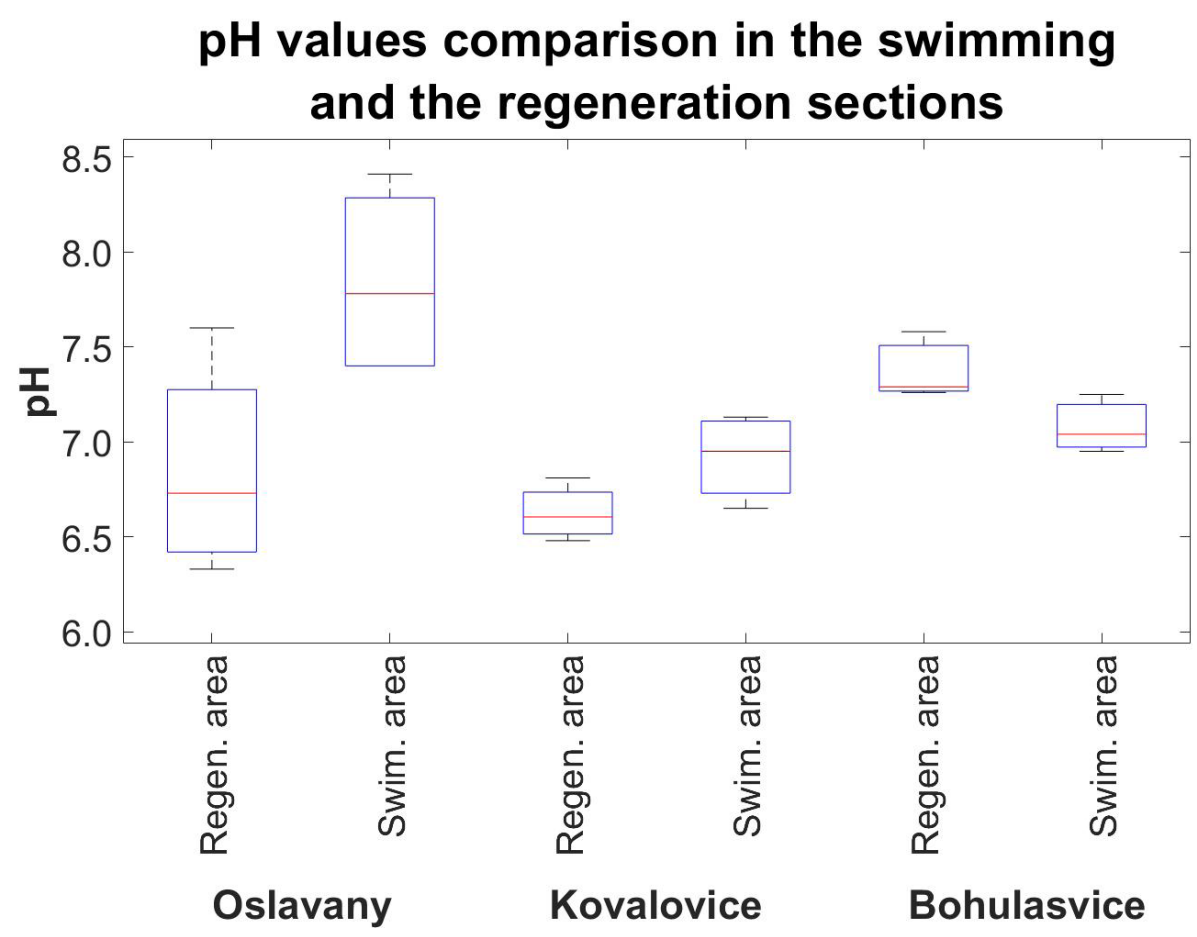

Fig. 14. Comparison of $\mathrm{pH}$ values in the regeneration and swimming sections. Source: author's archive. 


\section{Chlorophyll-a values comparison in the swimming and the regeneration sections}

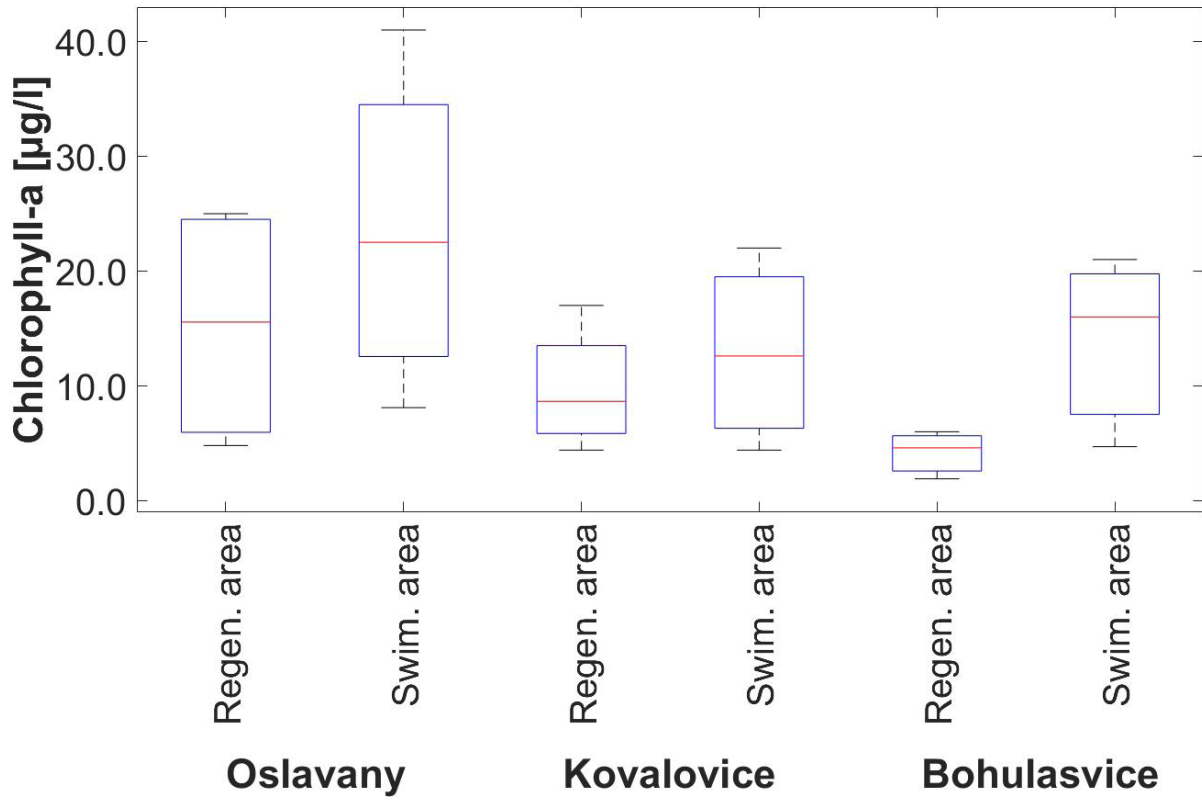

Fig. 15. Comparison of chlorophyll-a values in the regeneration and swimming sections. Source: author's archive.

Table 5. Comparison of joint measured values to the values obtained in an experiment conducted in Borovany and Sezimovo Ústí (Baxa et al., 2019).

\begin{tabular}{|c|c|c|c|c|c|}
\hline Zone & Swimming pool & $\begin{array}{l}\mathrm{N}-\mathrm{NO}_{3} \\
(\mathrm{mg} / \mathrm{l})\end{array}$ & $\begin{array}{l}\mathrm{P}-\mathrm{PO}_{4} \\
(\mathrm{mg} / \mathrm{l})\end{array}$ & $\begin{array}{l}\text { P-total } \\
(\mathrm{mg} / \mathrm{l})\end{array}$ & $\begin{array}{c}\text { Chlorophyll-a } \\
(\mu \mathrm{g} / \mathrm{l})\end{array}$ \\
\hline \multirow{5}{*}{ 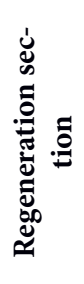 } & Oslavany & 14.75 & $<0.010$ & 0.014 & 15.2 \\
\hline & Kovalovice & 0.40 & $<0.010$ & 0.015 & 9.7 \\
\hline & Bohuslavice & 2.30 & $<0.010$ & 0.009 & 4.2 \\
\hline & $\begin{array}{c}\text { Borovany } \\
\text { (Baxa et al., 2019) }\end{array}$ & 0.69 & 0.011 & 0.320 & 12.2 \\
\hline & $\begin{array}{c}\text { Sezimovo Ústí } \\
\text { (Baxa et al., 2019) }\end{array}$ & 0.15 & 0.007 & 0.090 & 9.3 \\
\hline \multirow{5}{*}{ 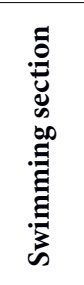 } & Oslavany & 13.5 & 0.145 & 0.015 & 23.5 \\
\hline & Kovalovice & 0.30 & $<0.010$ & 0.015 & 12.9 \\
\hline & Bohuslavice & 1.70 & $<0.010$ & 0.014 & 13.9 \\
\hline & $\begin{array}{c}\text { Borovany } \\
\text { (Baxa et al., 2019) }\end{array}$ & 0.60 & 0.010 & 0.360 & 17.7 \\
\hline & $\begin{array}{c}\text { Sezimovo Ústí } \\
\text { (Baxa et al., 2019) }\end{array}$ & 0.07 & 0.008 & 0.100 & 10.9 \\
\hline
\end{tabular}

Fig. 12, dissolved oxygen values in Fig. 13, pH values in Fig. 14 and chlorophyll-a in Fig. 15.

Comparison of the values of individual measurements within the terms of one nature swimming pool is not appropriate because each measurement is influenced by the mutual effects of various factors (e.g. air temperature, water temperature, accumulated number of visitors during the period between measurements, duration of sunlight, etc.). However, trends across all nature swimming pools can be observed, as well as the random phenomena typical for the specific swimming pool.

The results indicate that the highest value of $\mathrm{N}^{-\mathrm{NO}_{3}}$ is in Oslavany, which may be caused by intensive aeration or the generally intensive pre-treatment with a number of technologies (Pollice et al., 2002). This is the nature swimming pool with the most extensive technological system and simultaneously the least autonomy. During the last visit, the pump was switched off over- 
Ekológia (Bratislava) 2021: 40(4): 312-324

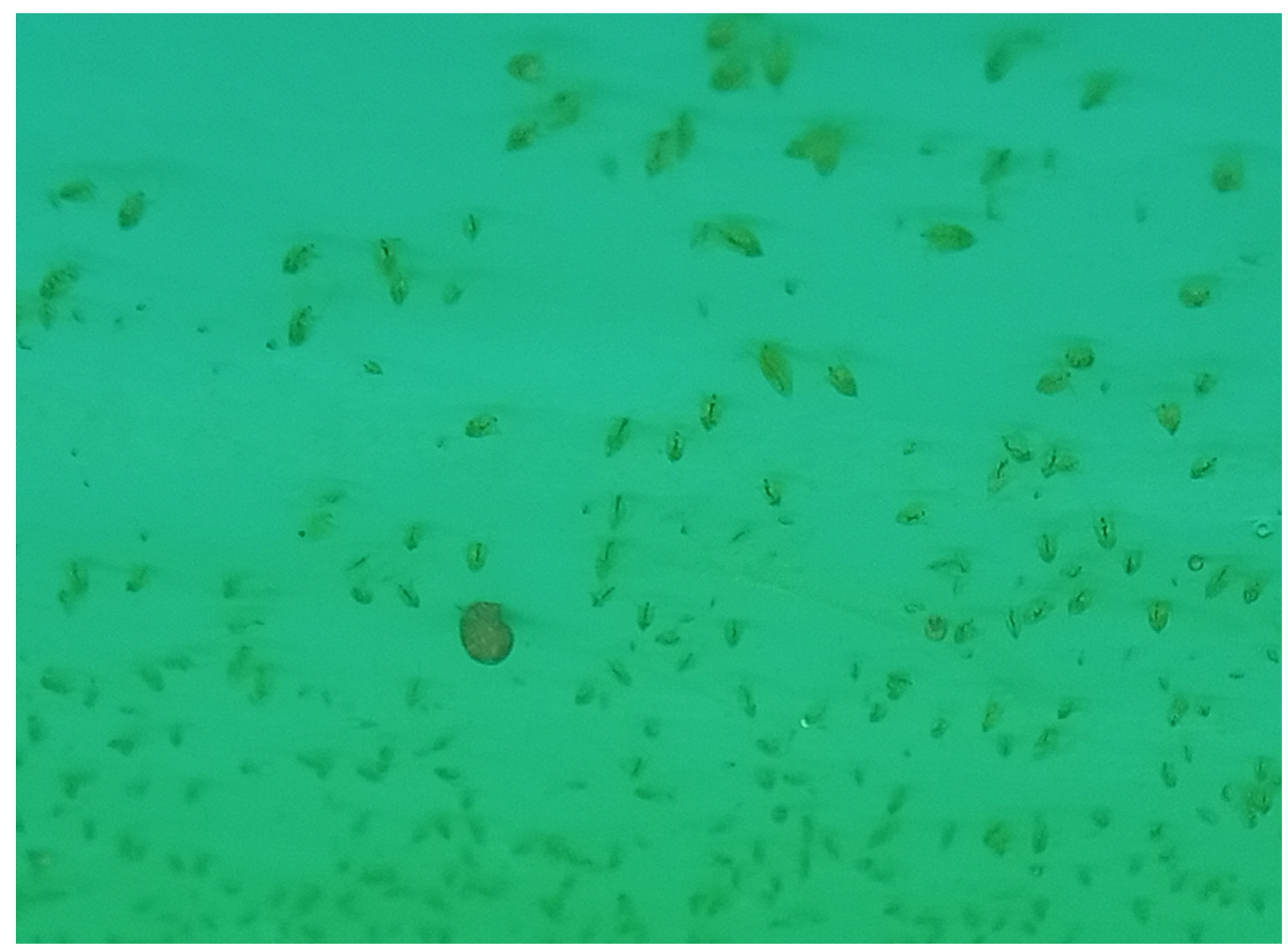

Fig. 16. Daphnia in the swimming section in Oslavany. Source: author's archive.

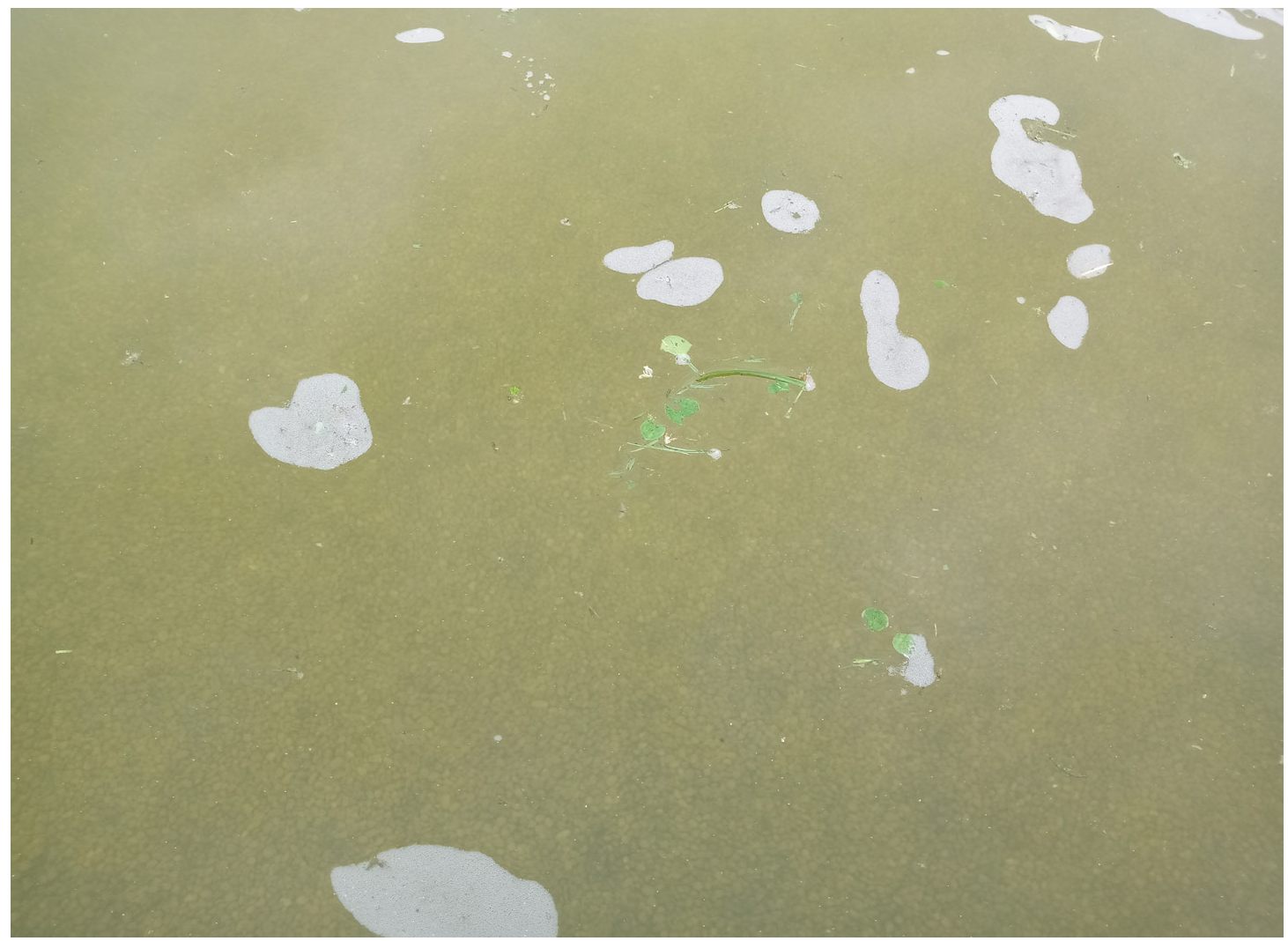

Fig. 17. Mowed grass on the surface of the nature swimming pool in Oslavany. Source: author's archive. 
night for the first time in the season, and this had a substantial visual impact on the quality of water. The declining quality can chiefly be attributed to the high ratio of swimming area to the volume or small depth of the pool. This makes the system less stable and leads to an imbalance more quickly (Pavlis, 2017). The $\mathrm{N}-\mathrm{NO}_{3}$ value in the swimming section during the last measurement, which was significantly lower than the previous values, is also an evidence of this fact. During aeration, the $\mathrm{N}-\mathrm{NO}_{3}$ values were also high in comparison with other experimental measurements (Baxa et al., 2019).

During the first visit, it was evident that this was a functioning ecosystem by the visibly good transparency of water and the presence of Daphnia in the swimming section, which have a beneficial effect on water purity (Shiny et al., 2005) (Fig. 16). However, as the season progressed, the presence of visible Daphnia declined. Allochthonous pollution from bathers or from mowed grass, observed in Fig. 17, was the cause of the declining quality of water. If nitrogenous fertilisers are applied to the adjoining extensive grassy area, this may result in occurrence of a large quantity of nitrogen in the form of alocthonnous pollution, which was confirmed by the analyses.

$\mathrm{N}-\mathrm{NO}_{3}$ values in the nature swimming pool in Bohuslavice were satisfactory. The higher $\mathrm{N}-\mathrm{NO}_{3}$ value compared to Kovalovice may be caused by aeration of water in the regeneration zone, thanks to the system of cascades and overflows. The quality of water did not seem too good visually because the small area of the regeneration zone and the high flow-through rate of water through the zone cause algea to be flushed into the swimming zone. The small area, with a relatively shallow depth, is therefore prone to overheating (Pavlis, 2017). The period for which water remains in the regeneration section may not be sufficient. The management of the swimming pool handles the unsatisfactory quality of water by draining water and adding fresh water from the water mains. The swimming pool is, therefore, colder, with a lower nutrient content.

No macroscopically visible zooplankton was observed in Bohuslavice, which is probably caused by the fish population in the regeneration section.

The nature swimming pool in Kovalovice had the lowest $\mathrm{N}-\mathrm{NO}_{3}$ values, which may be due to lack of aeration. On the other hand, it contained a significant quantity of total phosphorus, but minimum $\mathrm{P}_{-} \mathrm{PO}_{4}$ in water. However, this is the nature swimming pool with the most autonomy and is intervention free. Its great depth and large volume of water may contribute to the overall stability of the environment.

During the first visit to the nature swimming pool in Kovalovice, there were evident Calanoida in the swimming section.

The examined nature swimming pools registered total phosphorus values for mesotrophic environments (apart from Bohuslavice u Kyjova, where this concerns limit values), which are in conflict with the standards. However, the values for an oligotrophic environment were not exceeded significantly. Compared to other experimental measurements (Baxa et al., 2019), the values from this research are more consistent.

The purification capabilities of the examined systems are evident on the basis of chlorophyll-a. Chlorophyll-a is an identifier of water trophy because there was a positive correlation between the amount of chlorophyll-a and algae, and the biomass present in water (Boyer et al., 2009).
The values of dissolved oxygen, which is an indicator of the purity of water in the nature swimming pool, are significant, particularly for the swimming section of the swimming pool in Oslavany (mechanical aeration) and in Bohuslavice, where the regeneration system consists of a system of cascades and overflows (Kircher, Thon, 2019).

The best (highest) $\mathrm{pH}$ value was obtained in Oslavany. On the contrary, the worst (lowest) $\mathrm{pH}$ value was obtained in the nature swimming pool in Kovalovice. The ideal $\mathrm{pH}$ for nature swimming pools is 8.4 due to formation of a biofilm on the walls of the pool (Farb, 2020).

It can be assumed, on the basis of the difference in $\mathrm{P}_{-} \mathrm{PO}_{4}$ and total phosphorus values in samples, that all the nature swimming pools are capable of effectively eliminating free phosphorus from water. Total phosphorus is eliminated from water, thanks to the regeneration zone, which is evidenced by the difference in values of total phosphorous in the swimming section and regeneration section. Water flowing into the regeneration zone (water from the swimming section) always had a higher concentration of total phosphorus than water flowing from the regeneration zone.

Overall comparison of the averages of values obtained with the values obtained in an experiment (Baxa et al., 2019) carried out in Borovany and Sezimovo Ústí is presented in Table 5. Selected quality indicators are the same for both research projects. It is evident from the values of both experiments that the $\mathrm{N}-\mathrm{NO}_{3}$ values measured in Oslavany are very high compared to other swimming pools. The capability of all swimming pools to purify water by reducing the levels of chlorophyll-a in the regeneration zone is also evident. The swimming pools analysed in this experiment had a significantly lower amount of total phosphorus than the swimming pools analysed during the experiment (Baxa et al., 2019).

\section{Conclusion}

Designing a nature swimming pool is a complex matter, during which time the amount of nutrients entering the nature swimming pool, and which can be biologically or mechanically eliminated in order to maintain an oligotrophic environment, must be taken into consideration, as well as other issues.

The total volume of water in a system appears crucial for designing an autonomous nature swimming pool without extensive technological systems. The greater the volume and the greater the depth of the swimming pool, the greater its resistance to fluctuations. The area of the regeneration zone compared to the swimming zone also plays an appreciable role. This ratio should be as high as possible. Additional treatment technologies can be implemented to achieve the required quality of water in the pool.

There are a number of factors that affect the overall quality of the water in natural swimming pools and these depend on the time and weather. It is, therefore, advantageous to examine the specific issue on the basis of extensive research, taking into account multiple factors, particularly in the long term.

\section{References}

Association of nature swimming pools and ponds (2014). Standards for planning, building and managing nature swimming pools and ponds (in Czech). Brno: Association of Nature Swimming Pools and Ponds. 
Baumhauer, J. \& Schmidt C. (2008). Swimming pond construction: manual for planning, technology and operation (in German). Berlin-Hannover Patzer Verlag.

Baxa, M., Benedová, Z., Kröpfelová, L., Vlková, D. \& Šulcová J. (2019). Efficiency of regeneration zones in water treatment in natural swimming pools (in Czech). In Water Reservoirs 2019 (pp. 113-116). Brno: Povodí Moravy.

Bernard, A., Nickmilder, M., Voisin, C. \& Sardella A. (2009). Impact of chlorinated swimming pool attendance on the respiratory health of adolescents. Pediatrics, 124(4), 1110-1118. DOI: 10.1542/peds.20090032.

Boyer, J., Kelble, C., Ortner, P. \& Rudnick D. (2009). Phytoplankton bloom status: Chlorophyll a biomass as an indicator of water quality condition in the southern estuaries of Florida, USA. Ecological Indicators, 9(Suppl. 6), S56-S67. DOI: 10.1016/j.ecolind.2008.11.013.

Bratby, J. (2016). Coagulation and flocculation in water and wastewater treatment. London: IWA Publishing.

Decree No. 238/2011 Coll. (2011). Czech Republic.

Farb, A. (2020). A deep dive into natural swimming pool filtration: Living walls as technical wetland filters. Ph.D. Thesis, Utah State University, Logan, Utah.

Giampaoli, S., Garrec, N., Donzé, G., Valeriani, F., Erdinger, L. \& Spica V. (2014). Regulations concerning natural swimming ponds in Europe. Journal of Water and Health, 12(3), 564-572. DOI: 10.2166/ wh.2014.211.

Guardia-Puebla, Y., Pérez-Quintero, F., Rodríguez-Pérez, S., SánchezGirón, V., Llanes-Cedeño, E., Rocha-Hoyos, J. \& Peralta-Zurira D. (2019). Effect of hydraulic loading rate and vegetation on phytoremediation with artificial wetlands associated to natural swimming pools. Journal of Water Land Development, 40(1-3), 39-51. DOI: 10.2478/ jwld-2019-0004.
Håkanson, L. \& Bryhn A. (2008). Water pollution. Uppsala: Uppsala University.

Karczmarczyk, A., Bus, A. \& Baryła A. (2019). Influence of operation time, hydraulic load and drying on phosphateretention capacity of mineral filters treating natural swimming pool water. Ecological Engineering 130, 176-183. DOI: 10.1016/j.ecoleng.2019.02.018.

Kirche, W. \& Thon A. (2019). How to build a natural swimming pool. China: Filbert Press.

Littlewood, M. (2005). Natural swimming pools: inspiration for harmony with nature. Atglen: Schiffer Pub.

McGriff, C. \& McKinney R. (1972). The removal of nutrients and organics by activated algae. Water Res., 6(10), 1155-1164. DOI: 10.1016/00431354(72)90015-2.

Pavlis, R. (2017). Building Natural Ponds. Canada: New Society Publishers.

Pitter, P. (2015). Hydrochemistry (in Czech). Prague: University of Chemistry and Technology Prague.

Pollice, A., Tandoi, V. \& Lestingi C. (2002). Influence of aeration and sludge retention time on ammonium oxidation to nitrite and nitrate. Water Res., 36(10), 2541-2546. DOI: 10.1016/S0043-1354(01)00468-7.

Shiny, K., Remani, K., Nirmala, E., Jalaja, T. \& Sasidharan V. (2005). Biotreatment of wastewater using aquatic invertebrates, Daphnia magna and Paramecium caudatum. Bioresour. Technol., 96, 55-58. DOI: 10.1016/j. biortech.2004.01.008.

Sperling, M. (2007). Basic principles of waste water treatment. London: IWA Publishing.

Von Berger, F. (2010). Swimming ponds. Atglen: Schiffer Publishing Ltd. 